\title{
Contemporary Use of Phytocosmetics in Three Districts from North-Eastern Algeria
}

\author{
Amel Bouzabata
}

\section{Amel Bouzabata}

Laboratoire de Pharmacognosie, Faculté de Médecine, Rue Zaafrania BP 205, Annaba. ALGERIA

Correspondence

\section{Amel Bouzabata}

Laboratoire de Pharmacognosie, Faculté de Médecine, Rue Zaafrania BP 205, Annaba, ALGERIA.

Phone no: 00213553950019

E-mail: amelbouz2009@gmail.com

History

- Submission Date: 03-06-2017;

- Review completed: 21-07-2017;

- Accepted Date: 22-08-2017

DOI : 10.5530/pj.2017.6.120

Article Available online

http://www.phcogj.com/v9/i6

Copyright

(C) 2017 Phcog.Net. This is an openaccess article distributed under the terms of the Creative Commons Attribution 4.0 International license.

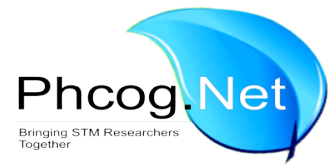

\begin{abstract}
Background: In Algeria, the cosmetic market is competitive, with an annual growth of $12 \%$. Because of the toxicity of synthetics cosmetics, the industry is currently more concentrated on herbal cosmetics. Phytocosmetic is an important aspect of traditional medicine in Algerian culture, whose information is scanty. Objective: The present study has been conducted to assess quantitatively the use of herbs in phytocosmetics application. Method: Data was collected from 300 users via face to face interviews using semi-structured questionnaire in three districts from North-eastern Algeria: Annaba, El Tarf and Skikda. Five parameters were evaluated including the demographic characteristics, the form of cosmetic preparation and, medicinal stories used in cosmetic applications. Results: The soap (67\%) and a fixed oil (56\%) were the preparation forms most used in phytocosmetics applications. Although, five medicinal plants were recorded: Aloe vera (L.) Burm. F., Matricaria recutita L., Lavandula angustifolia Mill., Citrus limon (L.) Osbeck and Ricinus communis $L$. The highest relative citation frequency (RFC) was attributed to $A$. vera in the three district Skikda (0.68), Annaba (0.57), and El Tarf (0.43). Eleven traditional recipes have been described. Conclusion: This study is able to record the available information the importance of phytocosmetic in traditional medicine. However, further research should be conducted in Algeria, to explore the toxicity of these products.

Key words: Algeria, Phytocosmetic, Toxicity, Traditional, Medicine, Scanty.
\end{abstract}

\section{INTRODUCTION}

Natural products have been for ages the first and often the only, source option for most of human necessities: from food to medicinal preparation, passing through materials and even for beauty purposes. ${ }^{1}$ Over the past decade there has been an increasing interest in the use of natural products. Since 1978, the World Health Organization (WHO) extent of the use of plants in health ecosystem. WHO has estimated that $80 \%$ of the world population relies chiefly on traditional medical system. ${ }^{2}$ Ethnobotanical uses of plants is useful approach for targeting leads in the development of new drugs. ${ }^{3-4}$ In recent time, there is an increase of interest in the use of traditional cosmetics, because they are considered less toxic, effective with an antioxidant effect. ${ }^{5}$ Plants have been found to be useful for various skin ailments and cosmetics. ${ }^{6}$ In spite of the stimulation of the studies involving medicinal plants by WHO, many traditional uses may not be validated as safe and efficacious by scientific methods. In Algeria, most ethnobotanical research has focused on documenting the diversity and traditional uses of medicinal plants. ${ }^{7-29}$ However, no written pharmacopeia has been made. To our knowledge, in Algeria no ethnobotanical study of medicinal plants used for cosmetics purposes has been published. Therefore, this study was conducted to assess the importance of phytocosmetic uses in three states for north-eastern Algeria.

\section{MATERIALS AND METHODS}

\section{Study area}

The research survey was conducted in three districts: Skikda, Annaba, and El Tarf located in north-eastern Algeria (Figure 1). The Annaba region (36 53'59" North, $7^{\circ} 46^{\prime} 00^{\prime \prime}$ East) is a coastal town situated in the central part of north-eastern Algeria, located $533 \mathrm{~km}$ from Algiers $\left(\operatorname{area}=1439 \mathrm{~km}^{2}\right)$. The El-Tarf region (36 $75^{\prime} 58^{\prime \prime}$ North, 8 $\left.8^{\circ} 22^{\prime} 12^{\prime \prime}\right)$ bordering Annaba district and located $589 \mathrm{~km}$ from Algiers $\left(\right.$ area $\left.=3339 \mathrm{~km}^{2}\right)$. The area of Skikda (36 52'34" North, 6 $6^{\circ}$ '33" East, area $=4026 \mathrm{~km}^{2}$ ) is located in the north-eastern Algeria, near Annaba, Guelma, Constantine district, and $471 \mathrm{~km}$ from Algiers.

\section{Data collection and field study}

Data were collected in 2015-2016 using semi-structured interviews. Three level of stratification were considered : the age, the sex and the education level. The characteristic of the population was provided from the data of National office of statistics. ${ }^{30}$

A total of 300 key informants were interviewed, five parameters have been analyzed: a) demographic characteristics including the age of the interviewed users, the sex, $b$ ) the level of education, $c$ ) the form of preparation used, $d$ ) the frequency of use, and $e$ ) the species cited. 


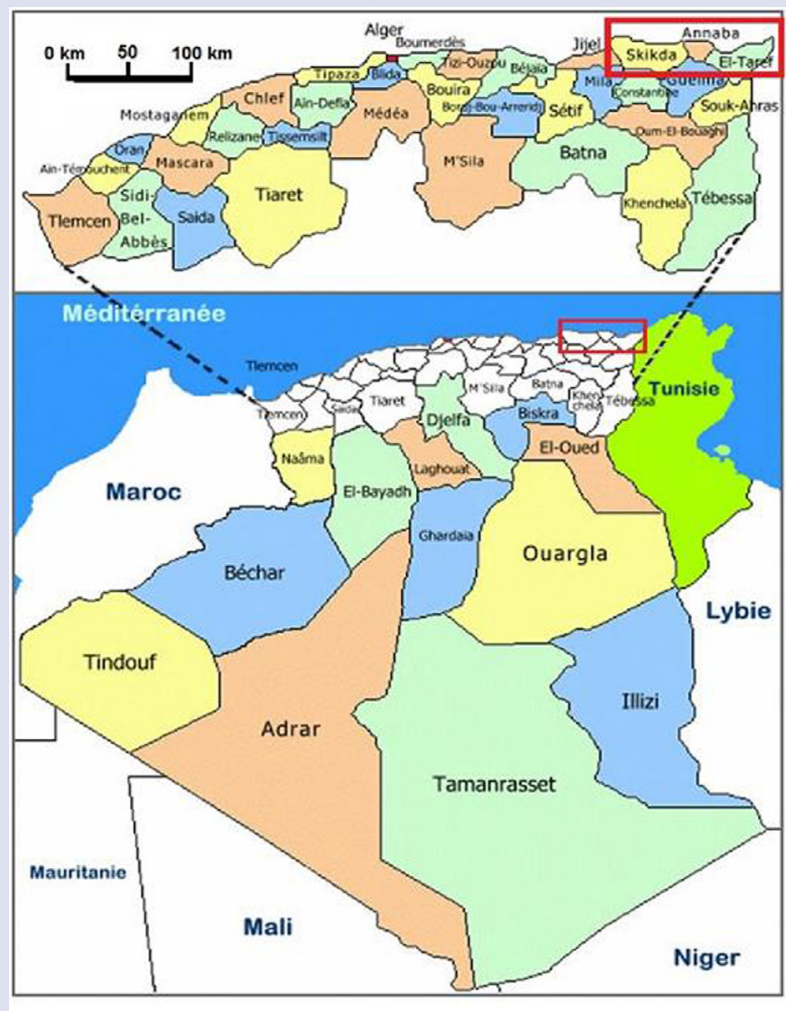

Figure 1: Geographical position of the study area.

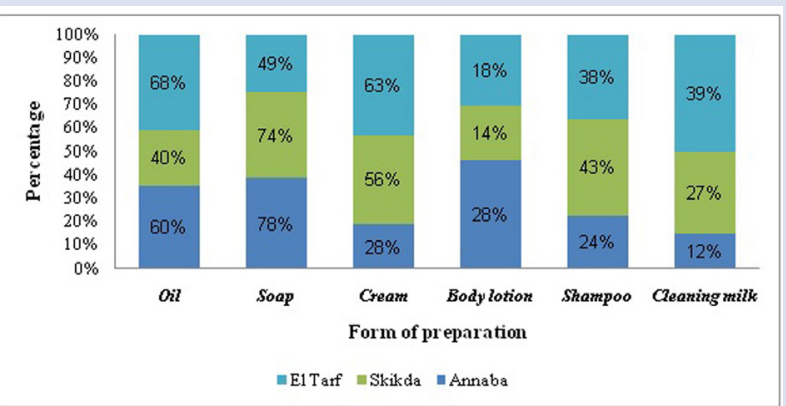

Figure 2: Distribution's form preparation of phytocosmetics in each district.

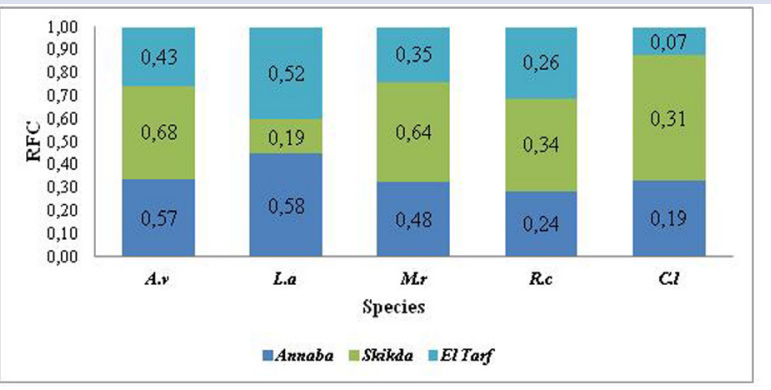

Figure 3: Distribution of RFC species cited in each district.

metics was investigated in each district. Based on a stacked bar chart to $100 \%$ (Figure 2), the soap was majoritary cited and used in Annaba (78\%) and Skikda (74\%), following by the hair oil in Annaba and the cream in Skikda district with percentage of $60 \%$ and $56 \%$, respectively. However, in El Tarf district, the hair oil and the cream were predominant $(68 \%, 63 \%)$. In addition, $60 \%$ of respondents indicated that the phytocosmetics are employed with the frequency of use once per day, or less frequently twice per day (13\%), once a week (15\%) and twice a week (12\%).

\section{Relative Frequency Citation of herbs used in phytocosmetic and Ethnobotany indices}

Five medicinal species have been recorded by the participants sampled, for phytocosmetic applications: Aloe vera (L.) Burm.F., Matricaria recutita L. and Lavandula angustifolia Mill. , Ricinus communis L. and Citrus lemon (L.) Osbeck. The figure 3 illustrates the repartition of each species mentionned by informant in each district. Based on stacked bar chart to $100 \%$ A. vera, L. angustifolia, and $M$. recutita were almost used in Annaba and El Taref district, with RFC values of [0.57, 0.58, 0.48], v.s $[0.43,0.52,0.35]$. However, A.vera, M. recutita, $R$. communis were predominant $[\mathrm{RFC}=0.68,0.64,0.34]$ in Skikda district.

\section{Correlation between climatic characteristics of the study area and the Form of preparation and RFC}

The Table 1 showed that there is no correlation between the form of presentation and climatic factors $(p<0.05)$, except for the soap. Indeed, it appeared that there is a positive correlation between the soap and the temparature ( $p=0.033$ ). For the Relative Frequence Citation (RFC) of species, it revealed that there is no relation between the popularity of each species and climatic factors. 
Bouzabata: Contemporary use of Phytocosmetics in North-eastern Algeria.

Table 1: Correlation between the climatic characteristics of the study area and form of preparation and RFC

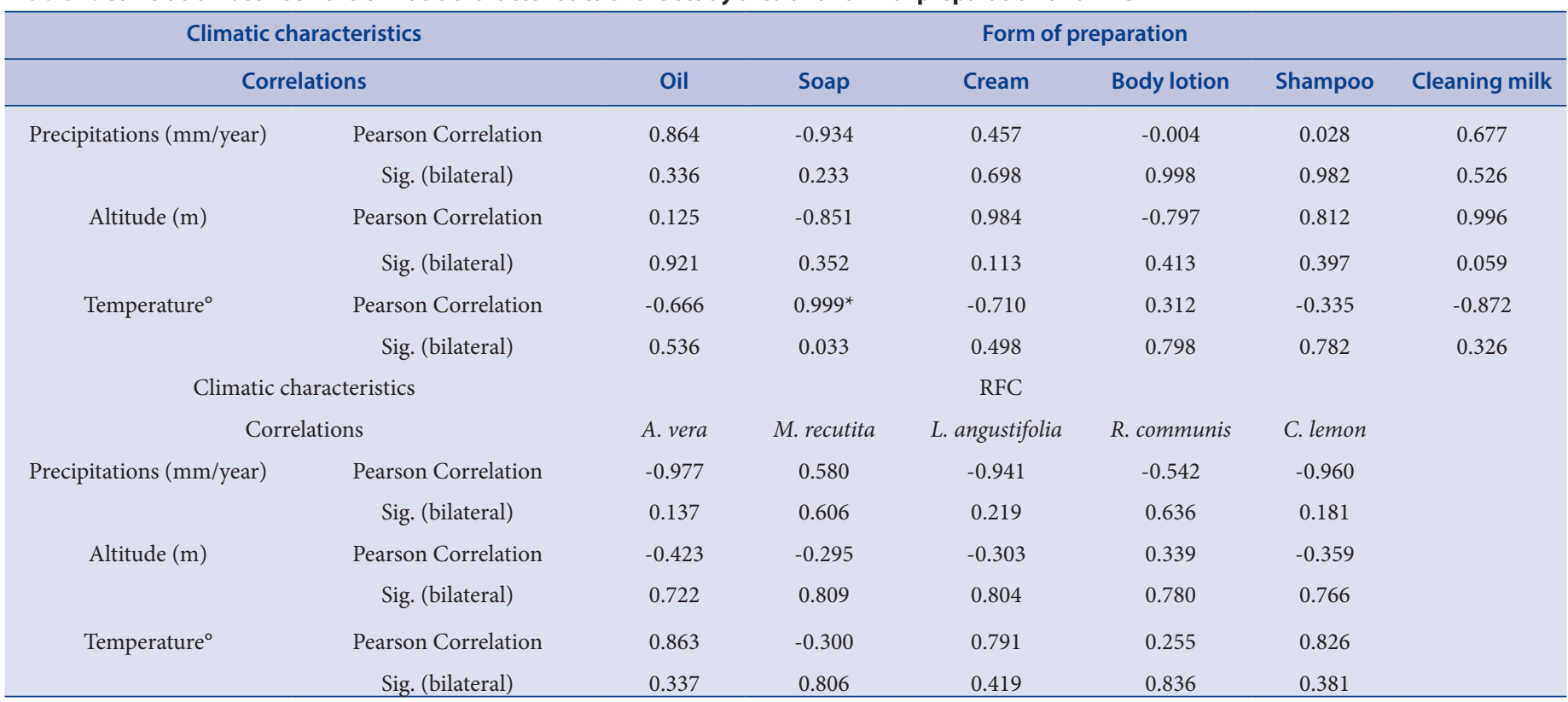

The correlation is significatif if $P^{*}<0.05$ (bilateral).

Table 2: Traditional home remedies used in phytocosmetics

Traditional recipes
1)Mash the strawberries, add the baking soda and mix until obtaining a consistent paste, apply this paste on the teeth, and keep for a few
minutes then rinse the mouth with water.
2) Mix turmeric spoon with a spoon of honey and a tablespoon chick + lemon juice+ a little almond oil. Mix the ingredients; apply the
mask on the face for 10 minutes.
3) A spoonful of oil of seeds Nigella sativa L. + a tablespoon of olive oil. Mix the ingredients, massage the face with this mixture and keep
for an hour, wash the face with soap and warm water.
4) Three teaspoons of honey+ a half of teaspoon of cinnamon powder. Mix the ingredients and apply on pimples for 10 minutes, rinse
with water.
5) A teaspoon of honey+ olive oil + lemon juice+ dry chamomile flowers. Mix the ingredients apply on hair and rinse after.
6) A tablespoon of baking soda, lemon juice. Mix the ingredients, heat the mixture and soak nails 5 minutes, rinse with warm water.
Apply to face the liquid honey with few drops of lemon, hold for 20 minutes and remove with warm water.
7) Mix the yeast with fresh egg yolk. Mix two tablespoons of yeast with a little rose water. Apply to face and keep for 25 minutes.
of hair
8) Mix two tablespoons of green clay with two spoons of corn oil but apply to face and keep for 15 - 20 minutes and remove with warm
water.
9) Two tablespoons of flour with a little raw milk. Keep for 15 minutes and remove with warm water.
10) Apply slices of cucumber on the face for 15 minutes
11) Mix one tablespoon of Rose water with one spoon of milk powder and honey. Keep it for 10 minutes and rinse with warm water.

\section{DISCUSSIONS}

Our results are in accordance with ethnobotanic survey described in tropical islands of Mauritus as well as in Italy, where the women are most frequent users of herbal cosmetics. ${ }^{34,35}$ In addition, as described in other study the most popular forms in topical preparations were dermatological cream, ointments and lotions. ${ }^{36}$

The highest relative citation frequency (RFC) was attributed to $A$. vera in the three district Skikda (0.68), Annaba (0.57), and El Tarf (0.43). Other ethnobotanical studies have identified $A$. vera in herbal remedies used in different countries. A. vera is one of the most widely used in herbal products for the treatment of various skin conditions and developed in industry. ${ }^{36}$ Although, A. vera was described in Nigeria as useful in the treatment of skin diseases facial cleansers and body cream. ${ }^{37,38}$ As far back as $3500 \mathrm{BCE}$, the use of $A$. vera was very ancient in times of an Egyptian. ${ }^{39}$ In Ayurveda medicine, $A$. vera is known as the treatment for skin diseases. ${ }^{40}$ For instance, $A$. vera leaves are usefull for skin burns. ${ }^{41,42}$ However, some studies reported the weak allergenic potential of A. vera. ${ }^{43,44}$ An additional, $A$. vera has been exhibited excellent pharmacological and cosmetic relevance and has been explored for skin hyperpigmentation problems. ${ }^{45}$ For instance, actually $A$. vera was formulated in an aqueous based gel system for topical therapy of wild acne vulagris. ${ }^{46}$ Furthermore, A. vera prepared gel was tested on the healing of skin wounds surgically induced in Wistar rats, and had showed promising 
effect on the wound healing process. ${ }^{47} \mathrm{~A}$. vera gel was explored in cream cosmetics for skin against UV-induced aging. ${ }^{48,49}$ The efficacy of ointment preparation on bedsores was reported. ${ }^{50}$

Other plants have been also cited in our study, and were published as being herbs with potential cosmetic value. The Comission E approved the external use for skin and mucous membrane inflammations. The chamomile is popular for irritations of skin and mucosa in any part of the body and for eczema. ${ }^{51}$

Although, the popular use of Lavandula angustifolia (lamiaceae family) as a perfume was reported in Italy. ${ }^{52}$ The fruit juice of Citrus limon was beneficial for the skin and in the treatment for hair loss. ${ }^{53,54}$ It was also revealed that the extract juice is applied directly for dry skin and for burns. ${ }^{6-39-45}$ The seed oil of Ricinus communis was used as ointment for skin diseases. ${ }^{51}$ Indeed, Ricinoleic acid is used as a source of the oil for the manufacture of soap as a cream base..$^{52}$

Taking into account previous studies on the traditional knowledge and practices in local cosmetics, it appeared that the use is recorded to botanical flora. Indeed, it was reported that the most species used as traditional cosmetic are lamiaceae in Egypt as well as in Morocco, consequence of its representation in local flora. ${ }^{53,54}$ In contrast; we could remark that in north-eastern Algeria there is no correlation between the local flora and the traditional use of phytocosmetics. For that purpose, aloe is infrequent in Algeria, mainly cultivated or subspontaneous on the coast, confused with Agave. In addition, aloe is represented in Algeria by Aloe succotrina Lam. known as «Sabr». Maghreb authors indicate the soucoutri (from Socotra) being the best, and term that names the plant and the juice extracted from its leaves. It should be noted that this species is used for the high blood pressure. ${ }^{12}$

In addition, eleven herbal preparations have been showed (Table 2), the drug was administrated along with honey, milk baking soda, flour, egg yolk. These supplement ingredients have been also reported in other ethnobotanical survey cited by Assamese people. It was also noticeable that the extract role of these materials is not clearly known. ${ }^{6}$

\section{CONCLUSION}

The importance of the traditional medicine in the preparation of natural phytocosmetics was highlighted in north-eastern Algeria. In this study, we didn't evaluate the risk of phytocosmetics for users. In spite of these limitations, this is the first study on phytocosmetics in Algeria. A. vera was the species most cited in herbal cosmetics. Therefore, there is no correlation between the traditional use in cosmetics and the local flora. The local knowledge is representing by heritage orally transmitted orally. Further extensive ethnobotanical and ethnopharmacological study may lead to the discovery of plants used for cosmetics.

\section{ACKNOWLEDGMENT}

The author thank to Pr Geoffrey Cordell, for his valuable advices in the redaction of this article.

\section{CONFLICT OF INTEREST}

Author declare that there is no conflict of interests regarding the publication of this paper.

\section{ABBREVIATION USED}

A.v: Aloe vera; L.a: Lavandula angustifolia; M.r: Matricaria recutita; R.c: Ricinus communis; C.l: Citrus limon.

\section{REFERENCES}

1. Costa IM. Phytocosmetics-Where Nature Meets Well-Being. Journal of Phytocosmetics and Natural Ingredients. 2015;2:1.
2. Farnsworth NR, Akerele O, Bingel AS, Soejarto DD, Guo Z. Medicinal plants in therapy. Bulletin of the world health organization. 1985;63(6):965.

3. Cordell GA. Changing strategies in natural products chemistry. Phytochemistry. 1995;40(6):1585-612.

4. Newman DJ, Cragg GM. Natural Products as Sources of New Drugs over the Last 25 Years $\perp$. Journal of natural products. 2007;70(3):461-77.

5. Saha R. Cosmeceuticals and herbal drugs: Practical uses. International Journal of Pharmaceutical Sciences and Research. 2012;3(1):59-65

6. Saikia AP, Ryakala VK, Sharma P, Goswami P, Bora U. Ethnobotany of medicinal plants used by Assamese people for various skin ailments and cosmetics. Journal of Ethnopharmacology. 2006;106(2):149-57.

7. Allali H, Benmehdi H, Dib MA, Tabti B, Ghalem S, et al. Phytotherapy of diabetes in west Algeria. Asian Journal of Chemistry. 2008;20(4):2701.

8. Azzi R, Djaziri R, Latifa F, Sekkal FZ, Benmehdi H, et al. Ethnopharmacological survey of medicinal plants used in the treatment of diabetes melitus in the north western and south western Algeria. J Med Plants Res. 2012;6(10):2041-50.

9. Benarba B, Ambroise G, Aoues A, Meddah B, Vazquez A. Aristolochia longa aqueous extract triggers the mitochondrial pathway of apoptosis in BL41 Burkitt's lymphoma cells. International Journal of Green Pharmacy. 2012;6(1):45.

10. Benarba B, Meddah B, Aoues A. Bryonia dioica aqueous extract induces apoptosis through mitochondrial intrinsic pathway in BL41 Burkitt's lymphoma cells. Journal of ethnopharmacology. 2012;141(1):510-6.

11. Benarba B, Meddah B, Tir Touil A. Response of bone resorption markers to Aristolochia longa intake by Algerian breast cancer postmenopausal women. Advances in pharmacological sciences. 2014.

12. Benarba B, Belabid L, Righi K, amine Bekkar A, Elouissi M, et al. Ethnobotanical study of medicinal plants used by traditional healers in Mascara (North West of Algeria). Journal of ethnopharmacology. 2015;175:626-37.

13. Benarba B. Ethnomedicinal study of Bryonia dioica, a plant used as anti-breast cancer herbal therapy in North West Algeria. Journal of Medicinal Herbs and Ethnomedicine Vol. 2015;1:113.

14. Houcine B, Rachid A, Rabah D, Farid L, Nabila B, et al. Effect of saponosides crude extract isolated from Citrullus colocynthis (L.) seeds on blood glucose level in normal and streptozotocin induced diabetic rats. Journal of Medicinal Plants Research. 2011;5(31):6864-8.

15. Boudjelal A, Henchiri C, Siracusa L, Sari M, Ruberto G. Compositional analysis and in vivo anti-diabetic activity of wild Algerian Marrubium vulgare $\mathrm{L}$. infusion. Fitoterapia. 2012;83(2):286-92

16. Boudjelal A, Henchiri C, Sari M, Sarri D, Hendel N, et al. Herbalists and wild medicinal plants in M'Sila (North Algeria): An ethnopharmacology survey. Journal of ethnopharmacology. 2013;148(2):395-402.

17. Amel B. Traditional treatment of high blood pressure and diabetes in Souk Ahras District. Journal of Pharmacognosy and Phytotherapy. 2013;5(1):12-20.

18. Bouzabata A, Bazzali O, Cabral C, Gonçalves MJ, Cruz MT, Bighelli A, et al. New compounds, chemical composition, antifungal activity and cytotoxicity of the essential oil from Myrtus nivellei Batt. \& Trab., an endemic species of Central Sahara. Journal of ethnopharmacology. 2013;149(3):613-20.

19. Bouzabata A, Cabral C, Gonçalves MJ, Cruz MT, Bighelli A, et al. Myrtus communis $L$. as source of a bioactive and safe essential oil. Food and Chemical Toxicology. 2015;75:166-72.

20. Chermat S, Gharzouli R. Ethnobotanical study of medicinal flora in the North East of Algeria-An empirical knowledge in Djebel Zdimm (Setif). J Mater Sci Eng. 2015;5:50-9

21. Halmi S, Benlaksira B, Bechtarzi K, Berouel K, Serakta M, et al. Pharmacotoxicological study of Opuntia ficus-indica L. aqueous extract in experimental animals. International Journal of Medicinal and Aromatic Plants. 2013;3(3):375-81.

22. Hammiche V, Maiza K. Traditional medicine in Central Sahara: pharmacopoeia of Tassili N'ajjer. Journal of ethnopharmacology. 2006;105(3):358-67.

23. Kambouche N, Merah B, Derdour A, Bellahouel S, Benziane MM, et al. Étude de I'effet antidiabétique des saponines extraites d'Anabasis articulata (Forssk) Moq plante utilisée traditionnellement en Algérie. Phytothérapie. 2009;7(4):197-201.

24. Maiza $K$, Hammiche $V$, Bounaga $N$, Brac de la Perrière RA. Inventaire des plantes médicinales de trois régions d'Algérie. Actes du Colloque International hommage à Jean Pernès. Complexes d'espèces, flux de gènes, ressources génétiques des plantes. Paris. 1992;631-33

25. Maiza K, Brac de la Perrière RA, Hammiche V. Traditional Saharian pharmacopoeia. Acta Hortic 1993a;332,37-42.

26. Maiza K. Brac de la Perrière RA, Hammiche V. InPharmacopée traditionnelle saharienne: Sahara septentrional. 2nd proc of European Conf on Ethnopharmacology \& 11th Int Conf Of Ethnomedecine. Heidelberg, France 1993 (pp. 169-171)

27. Maiza K, Brac de la Perrière RA, Hammiche V. Pharmacopée traditionnelle Saharienne. Revue Méd. Pharm. Afr. 1995;9:71-5

28. Meliani N, Dib ME, Allali H, Tabti B. Hypoglycaemic effect of Berberis vulgaris L. in normal and streptozotocin-induced diabetic rats. Asian Pacific journal of tropical biomedicine. 20111;1(6):468-71.

29. Ziane L, Lazouni HA, Moussaoui A, Hamidi N. Ethnopharmacology and phytochemical screening of bioactive extracts of Limoniastrum Feei (plombagenaceae). Asian Journal of natural and applied sciences. 2013:2(1):1.

30. ONS.dz. Alger: Office National des Statistiques, Population RGPH, 2008 [uptat- 
ed 2016 December 1]. Available from www.ons.dz/IMG/pdf/pop9_national.pdf. 31. http://www.theplantlist.org/

32. Mahomoodally MF, Ramjuttun P. A quantitative ethnobotanical survey of phytocosmetics used in the tropical island of Mauritius. Journal of Ethnopharmacology. 2016;193:45-59.

33. Vitalini S, Iriti M, Puricelli C, Ciuchi D, Segale A, Fico G. Traditional knowledge on medicinal and food plants used in Val San Giacomo (Sondrio, Italy)-An alpine ethnobotanical study. Journal of Ethnopharmacology. 2013;145(2):517-29

34. Corraza M, Virgili A, Toni G, Minghetti S, Tiengo S, et al. Level of use and safety of botanical products for itching vulvar dermatoses Are patch tests useful? Contact Derm. 2016;74(5):289-94.

35. Talal A, Natsheh FM. Plants used in cosmetics. Phytotherapy Res. 2003; 17(9):987-1000

36. Fred-Jaiyesimi A, Ajibesin KK, Tolulope O, Gbemisola O. Ethnobotanical studies of folklore phytocosmetics of South West Nigeria. Pharmaceutical biology. 2015;53(3):3138

37. Fathima A, Sujith $V$, Jagannath $P$, Akash $M$. General review on herbal cosmetics. IJDFR. 2011;2(5):140-65.

38. Datta HS, Paramesh R. Trends in aging and skin care: Ayurvedic concepts. J Ayurveda Integr Med. 2010;1:110-13.

39. Carrió E, Vallès J. Ethnobotany of medicinal plants used in Eastern Mallorca (Balearic Islands, Mediterranean Sea). Journal of Ethnopharmacology. 2012: 141(3):1021-40.

40. Lall N, Kishore N. Are plants used for skin care in South Africa fully explored? Journal of ethnopharmacology. 2014;153(1):61-84.

41. Ferreira M, Teixeira M, Silva E, Selores M. Allergic contact dermatitis to Aloe vera. Contact dermatitis. 2007;57(4):278-9.

42. Gomes J, Pereira T, Vilarinho C, Duarte MD, Brito C. Contact dermatitis due to Centella asiatica. Contact dermatitis. 2010;62(1):54-5.

43. Lall N, Kishore N. Are plants used for skin care in South Africa fully explored?. Journal of ethnopharmacology. 2014;153(1):61-84.
44. Herbal Medicine Expanded Commission E Monographs, 2000. American Botanical Council: file:///C:/HerbalMed2/Monograph/ChamomileflowerGerman html accessed 01.12.2016.

45. Pieroni A, Quave CL, Villanelli ML, Mangino P, Sabbatini G, et al. Ethnopharmacognostic survey on the natural ingredients used in folk cosmetics, cosmeceuticals and remedies for healing skin diseases in the inland Marches, CentralEastern Italy. Journal of Ethnopharmacology. 2004;91(2):331-44

46. Bhaskar G, Arshia S, Priyadarshini SR. Formulation and evaluation of topical polyherbal antiacne gels containing Garcinia mangostana and Aloe vera. Pharmacognosy magazine. 2009;5(19):93.

47. Khan AW, Kotta S, Ansari SH, Sharma RK, Kumar A, Ali J. Formulation development, optimization and evaluation of aloe vera gel for wound healing. Pharmacognosy magazine. 2013(Suppl 1):S6.

48. Ashawat MS, Banchhor M, Saraf S, Saraf S. Herbal cosmetics:" trends in skin care formulation". Pharmacognosy Reviews. 2009;3(5):72-9.

49. Kappor S, Saraf S. Efficacy study of sunscreens containing various herbs for protecting skin from UVA and Sunrays. Phcog Mag. 2009;5(19):238-48.

50. Matsuo K, Yagi A, Kabbash A. Case reports of bedsores using Aloe vera gel powder with high molecular weight. Pharmacognosy Research. 2009;1(3):136.

51. Linhares JF, Ming LC, Pinheiro CU, Rodrigues MI. Ethnobotany approach taperas of maroon communities of Alcántara, Maranhão, Brasil. Int J Pyhtocosmet Nat Ingred. 2015;2(3):1-3

52. Heinrich M, Barnes J, Gibbons S, Williamson EM. Natural Product Chemistry. In: Kinghorn DA, editor. Fundamentals of pharmacognosy and phytotherapy, $2^{\text {th }}$ ed. Churchill Linvingstone: Elsevier; 2012. p. 67.

53. Elansary HO, Mahmoud EA, Shokralla S, Yessoufou K. Diversity of Plants, Traditional Knowledge, and Practices in Local Cosmetics: A Case Study from Alexandria, Egypt. Economic botany. 2015;69(2):114-26.

54. Khabbach A, Libiad M, Ennabili A, Bousta D. Medicinal and cosmetic use of plants from the province of Taza, Northern Morocco. Boletín Latinoamericano y del Caribe de Plantas Medicinales y Aromáticas. 2012;11(1):46-60.

\section{GRAPHICAL ABSTRACT}

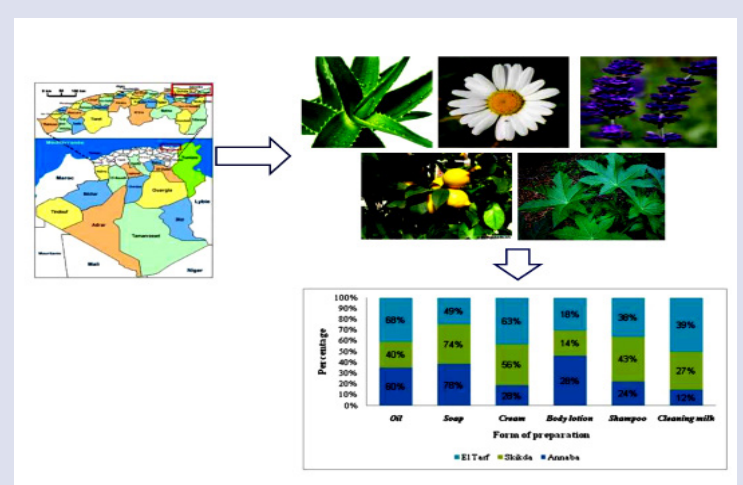

\section{SUMMARY}

The soap and the fixed oil were the preparation forms most used in phytoscosmetics application. Five medicinal plants have been recorded in this survey. Aloe vera L. was the species most cited by population from the three districts. There is no correlation between local flora and cosmetic use in Algeria.

\section{ABOUT AUTHOR}

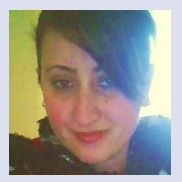

A. Bouzabata: Is research professor in the faculty of Medecine, Pharmacy Department, BadjiMokhtar University, Annaba, Algeria.

Cite this article: Bouzabata A. Contemporary Use of Phytocosmetics in Three Districts from North-Eastern Algeria. Pharmacog J 2017;9(6):762-6. 